\title{
Management of Prosopis Juliflora Invasion in Baringo County, Kenya through Utilization
}

\author{
Paul Tuwei $^{1^{*}} \quad$ Ebby Chagala Odera $^{2} \quad$ Jonah Kiprop $^{3} \quad$ Josephine Wanjiku $^{4}$ \\ Kenya Forestry Research Institute - Muguga, P.O Box 20412 00200, Nairobi Kenya
}

\begin{abstract}
Desertification in areas surrounding Lake Baringo in the early 1970's prompted introduction of Prosopis juliflora. The introduction and subsequent invasion of Prosopis juliflora has over the years attracted attention due to its negative impacts. Despite all the misconception surrounding its introduction Prosopis juliflora produces a variety of valuable goods and services. The study was conducted in Marigat Sub County in Baringo County to determine the economic contribution of Prosopis juliflora enterprises to household incomes and employment. The study involved administration of a structured questionnaire to 63 randomly selected members of the six Charcoal Producers Associations. The data was entered and analysed using SPSS statistical software. Descriptive statistics was used to establish how adoption of Prosopis enterprises is contributing to: reducing invasion, livelihoods and income. Findings indicated that all sampled respondents are involved in Prosopis charcoal production as the major enterprise; while $54 \%$ deal in fencing and construction poles, $54 \%$ pods, $48 \%$ honey, $44 \%$ firewood $41 \%$ and $35 \%$ timber. Incomes from charcoal were about Ksh 93.7 million in 2016. Earnings per annum from other Prosopis products namely pods, fencing/construction poles and honey totalled Ksh 12.2 million accounting for $12.9 \%$ of the total earnings. Prosopis charcoal market is dominated by brokers. Lack of reliable market (39.3\%), price fluctuation $(27.1 \%)$, poor state of roads during rainy season $(9.3 \%)$ and exploitation by middlemen were the main challenges experienced in marketing Prosopis products. From the study adoption and utilisation of Prosopis products is contributing significantly to livelihoods and income. However utilization of the species has not reduced its invasiveness.
\end{abstract}

Keywords: Charcoal, Desertification, livelihoods, invasive species, Prosopis juliflora

DOI: $10.7176 / \mathrm{JESD} / 10-10-09$

Publication date:May $31^{\text {st }} 2019$

\subsection{Introduction}

Concerns about deforestation prompted the introduction of Prosopis juliflora in the semi-arid areas of Kenya in the 1970's and 1980's (Johansson, 1985). Prosopis juliflora is an evergreen tree native to South America, Central America and the Caribbean. It is a hardy nitrogen-fixing tree that is now recognized as one of the world's most invasive alien species. It's fast growth; drought-resistant, evergreen characteristics rendered it an attractive candidate for arid land environmental rehabilitation programmes. P. Juliflora has survived in areas where most tree species have failed and in many is a nuisance (Mwangi and Swallow, 2005). The introduction and subsequent invasion of $P$. juliflora in Lake Baringo area of Kenya has over the years attracted national attention (Maundu, 2009). Despite all the misconception surrounding its introduction $P$. juliflora produces a variety of valuable goods and services including; construction materials, high quality charcoal, soil conservation and rehabilitation of degraded and saline soils (Pasiecznick et al., 2001).

Globally various countries have developed innovative ways of containing the spread and invasion of Prosopis. In India training on management and utilisation of Prosopis was initiated in Jodhpur 1993 to control the invasion in Rajastan (Muthana and Arora, 1983). Some of the key approaches for Prosopis control in India include utilisation of Prosopis wood as industrial fuel in small scale industries. Fence posts, poles, particle boards and cardboard are also manufactured using wood of P. Juliflora. In Sudan the prominent benefit of Prosopis to communities in addition to sand dune fixation includes; wood fuel and charcoal making. Records of commercially produced charcoal and firewood in 1996 from Gash and Atbara rivers were 600,000 sacks and 135,000 $\mathrm{m}^{3}$ respectively (Elsidig et al., 1998). In Yemen one method devised to reduce Prosopis invasion is ploughing heavily infested areas using tractors (FAO, 2006). In Kenya, to control and reduce the spread of $P$. juliflora, KEFRI in collaboration with various stakeholders have been involved in promoting 'management through utilisation'. Through this approach communities have been trained on utilisation of $P$. juliflora as a source of alternative livelihood. The enterprises that have been created through these interventions include; charcoal making, fodder, poles, honey and fuel wood. This study was undertaken to; determine the economic contribution of Prosopis juliflora enterprises to household incomes and employment in Baringo County Kenya and establish if adoption of Prosopis juliflora enterprises can sustainably act as an effective management strategy for control of Prosopis invasion. 


\subsection{MATERIALS AND METHODS}

\subsection{Study Site}

The study was carried out in Marigat Sub County, Baringo County. The study site is located in a $900 \mathrm{~km}^{2}$ area between latitudes $0^{\circ} 20^{\prime} \mathrm{N}$ and $4^{\circ} 44^{\prime} \mathrm{N}$ and Longitudes $35^{\circ} 57 \mathrm{E}^{\prime}$ and $36^{\circ} 12 \mathrm{E}^{\prime}$ and has the highest level of Prosopis juliflora invasion and colonisation.

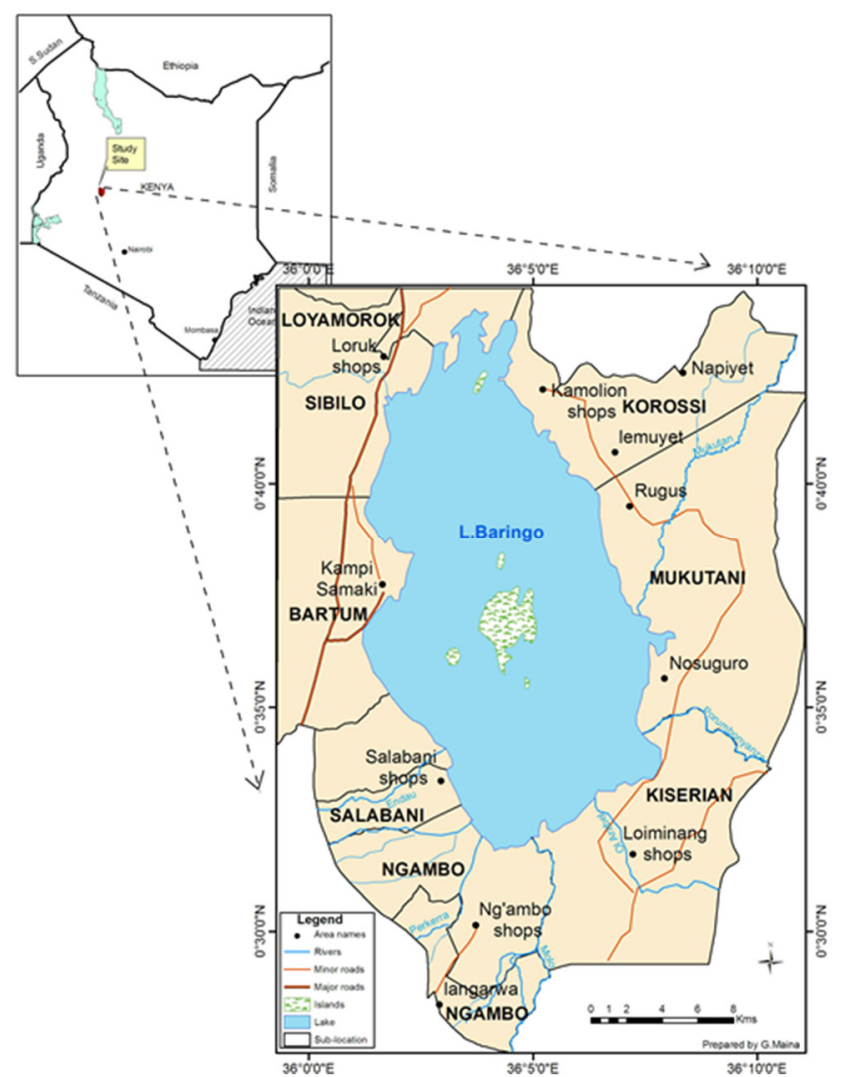

Figure 1: Map showing study sites around Lake Baringo, Kenya

The area falls under the category of marginalized areas in Kenya, with annual mean annual rainfall of 650 $\mathrm{mm}$ and temperature range of between $30^{\circ} \mathrm{C}$ to $35^{\circ} \mathrm{C}$. Main economic activities revolve around livestock and honey production. Crop production is practised under irrigation near Lake Baringo. The harsh arid conditions and land degradation prompted the introduction of Prosopis in the early 1980's. This study focused on administrative locations of Salabani, Ngambo, Kiserian, Lokisacha, Nalepo and Roteti as they represent areas with high densities of Proposis juliflora invasion. In each location all Charcoal Producers Associations (CPA's) dealing in utilisation of Prosopis biomass were selected for the study.

\subsection{Data collection and analysis}

A Multi-stage sampling procedure was used to select the sample for the study. In the first stage, Baringo County was purposively sampled because it is in this region that Prosopis was first introduced in the early 1980's. In the second stage Marigat Sub County was selected because of the high level of invasion in the areas surrounding Lake Baringo, also there are established groups formed specifically dealing in the extraction and utilisation of Prosopis products. In the third stage, systematic random sampling was applied to choose respondents from the list obtained from the Charcoal Producers Associations (CPA'S) dealing in Prosopis products. A structured questionnaire was administered to 63 randomly selected members of the Charcoal Producers Associations (CPAs) who were involved in the extraction and utilisation of Prosopis. Respondents were drawn from six Charcoal Producers Associations (CPA) namely; Ngambo, Roteti, Nalepo, Kiserian, Salabani and Lokasacha. Data was entered and analysed using SPSS statistical software. Descriptive statistics was used to establish how adoption of the Prosopis enterprises is contributing to; reducing invasion, livelihoods and income.

\subsection{RESULTS}

\subsection{Adoption of Prosopis Enterprises}

The study identified six major CPA namely; Ngambo, Roteti, Nalepo, Kiserian, Salabani and Lokasacha which have been formed to collectively exploit and use Prosopis biomass for various uses; charcoal, fencing and construction poles, pods, honey, firewood and timber. Most of the Prosopis raw material is extracted from 
community land (61.9\%) while $38.1 \%$ is obtained from private land. All the sampled $63(100 \%)$ respondents are involved in harvesting, processing and sale of Prosopis products. Charcoal production was the most adopted enterprises as cited by 63 respondents $(100 \%)$ followed by fencing and construction poles $(54 \%)$, pods $(48 \%)$, honey 44\%, firewood (41\%) and timber 35\% (Table I).

Table I: Prosopis products

\begin{tabular}{lll}
\hline Prosopis product & $\begin{array}{l}\text { Frequency } \\
\text { (n) }\end{array}$ & $\begin{array}{l}\text { Percentage of respondents involved in the } \\
\text { enterprise (\%) }\end{array}$ \\
\hline Charcoal & 63 & 100 \\
Fencing and construction poles & 34 & 54 \\
Pods (for livestock and fodder) & 30 & 48 \\
Honey & 28 & 44 \\
Firewood & 26 & 41 \\
Timber & 22 & 35 \\
\hline
\end{tabular}

Source: Author's analysis of survey data

\subsection{Economic contribution of Prosopis Juliflora enterprises to livelihoods}

Prosopis juliflora produces a wide range of products. CPA group earnings from charcoal totalled Ksh 93.7 million in 2016 accounting for $87.1 \%$ of the total group earnings. Ngambo CPA earned the highest amount at Ksh 54 million from sales of 132,678 bags of charcoal (Table II).

Table II: CPA's earnings per annum from Prosopis charcoal sales in 2016

\begin{tabular}{llll}
\hline Name of group & $\begin{array}{l}\text { Price per } \\
\text { Ksh (bags) }\end{array}$ & $\begin{array}{l}\text { unit } \\
\text { (Bags) }\end{array}$ & $\begin{array}{l}\text { Income from charcoal per } \\
\text { year (Ksh) }\end{array}$ \\
\hline Ngambo CPA & 407 & 132,678 & $54,000,000$ \\
Salabani CPA & 403 & 38,114 & $15,360,000$ \\
Roteti CPA & 400 & 28,800 & $11,520,000$ \\
Kiserian CPA & 405 & 18,963 & $7,680,000$ \\
Nalepo CPA & 400 & 6,760 & $2,704,000$ \\
Lokasacha CPA & 400 & 6,240 & $2,496,000$ \\
\hline Total & & $93,760,000$ \\
\hline
\end{tabular}

Source: Author's analysis of survey data

Earnings from other Prosopis products namely pods, fencing/construction poles and honey totalled Ksh 12.2 million accounting for $12.9 \%$ of the total earnings from Prosopis products proceeds in 2016 . Most of the earnings from other Prosopis products, Ksh 10.8 million came from sale of pods by Ngambo CPA (Table III). Honey and construction poles sales accounted for the least sales during the period. Timber and firewood are mainly utilised for domestic use and are harvested according to need as there was no high demand for the products.

Table III: CPA's Earnings per annum from Prosopis fencing poles, honey and pods sales in 2016

Product Group Sales from prosopis products in Ksh per annum

\begin{tabular}{llllllll} 
& Kiserian & Lokasacha & Nalepo & Ngambo & Roteti & Salabani & Total \\
\hline Poles & 75,000 & - & 30,000 & 96,000 & - & 704,700 & 905,700 \\
Honey & 80,000 & 84,500 & - & 16,000 & 4,000 & 16,250 & 200,750 \\
Pods & - & - & - & $10,822,000$ & - & 261,200 & $11,083,200$ \\
\hline Total & 155,000 & 84,500 & 30,000 & $10,934,000$ & 4,000 & 982,150 & $12,189,650$ \\
\hline
\end{tabular}

Source: Author's analysis of survey data

Trading in Prosopis products is the major source of income amongst the respondents. Apart from trading in Prosopis products the respondents were involved in crop farming (57\%) and livestock farming (33.3\%). Prosopis enterprises provided employment to household members as harvesting, processing and transportation of Prosopis and its products is done using human labour.

\subsection{Marketing of Prosopis products}

The Prosopis charcoal market is dominated by brokers who account for $100 \%$ of the market share. Most of the charcoal is sold to major market outlets in Nairobi, Kisumu, Eldoret and Nakuru. Fencing poles and pods are bought by local consumers directly. Firewood is mostly bought by consumers $(60 \%)$ and wholesalers $(40 \%)$. The prevailing market prices for the various prosopis products were determined by market dynamics of demand and supply $(82.9 \%)$, seasons $(8.6 \%)$, County government regulations (4.3\%), Charcoal Producers Association bargaining power $(2.9 \%)$ and distance to raw material (1.4\%). Market demand in key major towns of Nairobi, Kisumu and Eldoret play a significant role in determining the prevailing prices for charcoal with the average farm gate price retailing at Ksh 403 per bag. 


\subsection{Challenges in marketing and utilization of Prosopis products}

The main challenges experienced in marketing of Prosopis products include; lack of reliable market (39.3\%), price fluctuation $(27.1 \%)$, poor state of roads during rainy season $(9.3 \%)$ and exploitation by middlemen $(6.5 \%)$ as shown in Table IV.

Table IV: Challenges experienced in marketing prosopis products

\begin{tabular}{lll}
\hline Challenges experienced when marketing Prosopis products & Frequency & Percentage \\
\hline Lack of reliable market & 42 & 39.3 \\
Price fluctuation & 29 & 27.1 \\
Poor roads during rainy season & 10 & 9.3 \\
Exploitation by middlemen & 7 & 6.5 \\
Poor quality charcoal & 3 & 2.8 \\
Flooding & 3 & 2.8 \\
Insecurity & 3 & 2.8 \\
Difficulty in acquiring movement permits & 2 & 1.9 \\
Others & 8 & 7.2 \\
\hline Total & 107 & 100.0 \\
\hline
\end{tabular}

Challenge experienced during utilisation of Prosopis include; sharp thorns (47.2\%), invasiveness (25.6\%) and loss teeth in goats $(20.0 \%)$ when goats feed on the pods (Table V).

Table V: Challenges in utilising Prosopis

\begin{tabular}{lll}
\hline Challenges in utilising Prosopis & Frequency & Percentage \\
\hline Sharp thorns & 59 & 47.2 \\
Invasiveness & 32 & 25.6 \\
Loss of teeth in goats & 25 & 20.0 \\
Tree is difficult to cut down & 4 & 3.2 \\
High carbon emission when producing charcoal & 3 & 2.4 \\
Fast growth along river courses & 1 & 0.8 \\
High coppicing ability & 1 & 0.8 \\
\hline Total & 125 & 100.0 \\
\hline
\end{tabular}

\subsection{Discussion}

The introduction and subsequent invasion of Prosopis within areas surrounding Lake Baringo have brought mixed results. Despite the negative effects of the plant, through training on utilisation of Prosopis, residents living within these areas have been able to get an alternative source of livelihood apart from livestock and crop farming. This findings indicate that the products namely; charcoal, fencing poles, pods, honey and firewood contribute significantly to respondents' livelihoods both at domestic and commercial scale. The survey indicates that charcoal enterprise accounts for the highest share of the sales revenue earned by the six groups. Charcoal prices are determined by season, with prices being high during the rainy season and low during the dry season. During the rainy season demand for charcoal increases due to increase in household demand. Charcoal making and transportation from Prosopis extraction sites is also hampered by heavy rains and poor roads thus reducing supply. The CPAs bargaining power also influences the amount paid for to the group members. The other products; firewood, honey and timber are mainly consumed hence their prices are mainly negotiated by the buyers.

This finding corroborates other studies. In one village in Malawi studies found that $44 \%$ of the people relied on Prosopis as a primary source of income (Chikuni et al., 2004). As dry fodder Prosopis pods provide supplementary feed to livestock, and contains about $15 \%$ crude sugar and $12 \%$ crude protein (Sawal et al., 2004) in most parts of Baringo Prosopis has become a major source of dry season feed for goats and sheep. Energy from Prosopis obtained through direct burning and carbonisation are good sources of fuel. In Ethiopia P.juliflora is used to produce charcoal sustainably with a well-established market (Kwaschik, 2008; EPP, 2006).

\subsection{CONCLUSIONS}

The findings of this research indicate that majority of the respondents have adopted charcoal utilization technology. The technology is contributing significantly to their livelihoods and income. The use of the technology has not reduced the invasiveness of Prosopis. To improve income and livelihoods from the Prosopis enterprise, the study recommends the following; improve market linkages for the products, provide capital for associations, training on business techniques and mechanize harvesting of Prosopis.

\subsection{ACKNOWLEDGEMENT}

We are indebted to KEFRI for the financial support in carrying out this study. Enumerators who collected the data are also highly acknowledged, finally, we wish to sincerely thank all the farmers who answered our questions through the questionnaires. 


\subsection{REFERENCES}

1. Chikuni, M. F., Dudley, C. O., \& Sambo, E. Y. (2005). Prosopis glandulosa Torrey (leguminosae-Mimosoidae) at Swang'oma, Lake Chilwa plain: A blessing in disguise?. Malawi Journal of Science and Technology, 7(1), $10-16$.

2. Elsidig, N. A., Abdelsalam, A. H., \& Abdelmagid, T. D. (1998). Socio-economic, environmental and management aspects of mesquite in Kassala State (Sudan). Institute of environmental studies and ford foundation, SSFS.

3. EPP 2006. Proceeding of the WorKshop on Afar Pastoralist Prosopis Project Immerging Issues.

4. FAO, (2006). Problems posed by the Introduction of prosopis spp. In selected countries pp 35.

5. Kwaschik, R. 2008. Proceedings of the Conference on Charcoal and Communities in Africa

6. Maundu, P., Kibet, S., Morimoto, Y., Imbumi, M., \& Adeka, R. (2009). Impact of Prosopis juliflora on Kenya's semi-arid and arid ecosystems and local livelihoods. Biodiversity, 10(2-3), 33-50.

7. Muthana, K. D., \& Arora, G. D. (1983). Prosopis juliflora (Swartz) DC, a fast growing tree to bloom the desert.

8. Mwangi, E., \& Swallow, B. (2005). Invasion of Prosopis juliflora and local livelihoods: Case study from the lake Baringo area of Kenya. Nairobi, Kenya: World Agroforestry Centre.

9. Pasiecznik, N. M., Felker, P., Harris, P. J., Harsh, L., Cruz, G., Tewari, J. C. \& Maldonado, L. J. (2001). The 'Prosopis Juliflora'-'Prosopis Pallida' Complex: A Monograph (Vol. 172). Coventry: HDRA.

10. Sawal, R. K., Ratan, R., \& Yadav, S. B. S. (2004). Mesquite (Prosopis juliflora) pods as a feed resource for livestock-A review. Asian Australas J Anim Sci, 17, 719-725. 